\title{
Using Picture Series in Teaching Writing Skill for Students of Midwife Program
}

\author{
Lidia Deviga', Radian Arum Ardhani ${ }^{2}$ \\ STIKES Bhakti Husada Mulia Madiun ${ }^{1,2}$ \\ Devigalidya@gmail.com¹, radianarum@gmail.com²
}

\begin{abstract}
The aim of this research was to find out the using picture series in teaching writing skill for the fourth semester students of midwifery program in STIKES Bhakti Husada Mulia Madiun. This study was done on May 2020. The subjects were 32 students of the fourth semester students of midwifery program of STIKES Bhakti Husada Mulia Madiun in the academic year 2020/2021. The method used in this research was a qualitative descriptive research design. The techniques for collecting data were observation, interview, and documentation. During the research, the researcher acted as the teacher and observer during the implementation of picture series. The findings of observation show that there is good interaction between lecturer and students. The lecturer gives the task and assignment to make the students understand the material well. The finding of interview shows that by using picture series, the students can have the ideas how to start writing recount text well. They can arrange the picture series to help them in composing the writing. By using picture series the students can improve their writing based on the criteria asked by the lecturers. The criteria of the writing are vocabulary, content, language, mechanic and organization. The finding of documentation shows that the use of picture series in teaching writing recount text make the students interested. Thus, the learning process is supported that the students are better to write from their experiences to compose recount text. Then, the use of picture series is effectively used in helping students improve their performance in writing recount text. The future researcher can conduct the use of picture series in other skill of English such as on speaking skill. It is hoped can be used as the easy media to express the students' creativity in their speaking. Furthermore, the researcher can do this study by using the other design such as the experimental research design in teaching English writing skill.
\end{abstract}

Keywords: Picture Series, Writing, EFL.

\section{Introduction}

Writing is one of four basic language skills. It is very important in teaching and learning English. It involves some language components such as spelling, grammar, vocabulary, and punctuation. Braine \& May (1996) stated that writing clear sentences requires writers to learn the rules of English grammar and mechanics such as the correct use of verb pronoun and other punctuations. Styati \& Latief (2018) mentioned that writing can be analyzed based on content, organization, vocabulary, grammar and mechanics. There are various ways to organize sentences in a piece of writing. The text organization can be represented by several text types; one of them is a recount text.

A recount text is a text which retells events or experiences in the past. The purpose is either informing or entertaining. In a recount text, sentences are usually organized according to time order or chronological order. One event happens and then another event 
happens, and the events are told in the same order. There are many studies on teaching recount text conducted by many researchers. Mardiana (2014) and Albert (2014) have conducted the research on recount text by using picture series. The results of using picture series are to solve the students' problems as well as improving their writing comprehension skill. In his research, Syafi'i (2016) proved that the use of picture series is effective to improve the students writing. Apsari (2017) has conducted the research on recount text by using picture series. The results reveals that the teaching writing by using picture series can improve students' ability in writing recount text. It shows the improvement on process of writing and vocabulary on recount text.

Based on the research, teaching writing skill of the recount text has some problems. In the first problem is that the students' writings are not comprehensible because the content of the composition is not relevant to the topic. The students lack the ideas to write the sentences. It may stand from the student lack of understanding on the function of text, steps in text writing recount text. The second problem is many errors in vocabulary, grammar, and spelling. It indicates that the student's mastery on the English components of the text is still low. Students' writing skill must be developed to make students explore their idea, creativity and knowledge.

The lecturers help them in developing their skill and ability by using method, technique, and media. It is considered to help the students to understand the text easier. In addition, it is necessary to do something different to have students writing skill improved. Therefore, English lecturer should improve their professionalism on teaching writing and should motivate students to more actively learn English. English lecturers ought to create more conducive classroom that can implement some methods. It can use various media in teaching and learning process since using media can help the students better understand the materials in the classroom (Berk, 2014). One of media that can be used in the class is picture series.

Picture series are helping the students to improve the student's ability in writing skill because it will encourage students to participate more actively in teaching and learning process while using pictures series in telling events. By using this media, the students are expected to be able to tell some pictures. Many studies support this study such as (Azhari, 2004; Novita, 2014) that picture series have been used to help the students in writing. Picture series are the authentic materials that can enhance the teaching learning process in writing (Rahman, 2013). Therefore, the aim of the study is to know the implementation of using picture series in teaching writing skill for the fourth semester students of midwifery program in STIKES Bhakti Husada Mulia Madiun.

\section{Method}

This research used a qualitative descriptive research method. The respondents of the research are an English lecturer and fourth semester students of midwifery program of STIKES BHM Madiun. The study was conducted in midwifery program of STIKES BHM Madiun. There were 32 students involved in this study. The students were given the subjects in writing which aimed to develop the types of the writing for instance descriptive, procedure, narrative, recount, and etc. The study was about composing recount text. It is a descriptive research. It is the research conducted with the main objective to provide description of a situation objectively.

To describe the existing phenomena, whether a natural phenomenon or man-made phenomenon, it could be seen from the shapes, activities, characteristics, changes, 
relationships, similarities and differences between one phenomenon with other phenomena. Sukmadinata (2006) argued that descriptive research is research that seeks to describe and interpret things, such as the condition or relationship, a growing opinion, the ongoing processes, results or effects.

The data are obtained from observation, interviews, and documentation. Arikunto (2010) mentioned that observation is by completing blank format as an instrument of observation. Observation means that the researchers record the information as they truly observed during the study. There was using of observation guideline to get the data. Furthermore, Arikunto (2010) also mentioned that the interview is the collection of data by asking questions directly to the respondents in detail in the form of check list. It used the guideline checklist of interview to ask the questions to the interviewee. Moreover, Arikunto (2010) mentioned that documentation is looking for data about things or variables in the form of notes, transcripts, books, newspapers, magazines, inscriptions, minutes of meetings, agendas and so forth. In this study, the data of documentation from the preparation of the teaching learning process namely lesson plan, the materials, and the other documentation is the students' scores.

The data were analyzed by reducing, displaying and drawing conclusions of the data. Sukardi (2006) stated that the data collection in a qualitative descriptive study, in general, can be done by (1) reducing the data, (2) displaying the data (3) drawing conclusions and verification.

\section{Results}

The analysis of the data from the observation and interview showed that the use of picture series was effectively used in helping students' improve their writing ability. The result of observation of the teaching learning process has been done well. Lecturers do some preparations in teaching writing of recount text by using several steps of planning, implementation and evaluation. The lecturer also designs the lesson plan. There are competence standard which are base competence, indicator, instructional objective, material, method, teaching and learning activities, source of teaching and assessment. The implementation of using picture series can be done in three steps namely opening, whilst, and closing activity. After that, before beginning the lesson, the lecturer gives motivation to make the students excited to join the lesson.

A whilst activity has been conducted using exploration, elaboration, and confirmation. Then, the lecturer starts explaining to the students about definition, generic structure and language feature about writing recount text. The students pay attention and listen to the explanation of lecture. And then, the lecturer gives example by providing of the text. Then, the lecturer explains on how to determine the characteristics of pictures and give examples about how to make recount text. Based on the pictures series given by the lecturer, the lecturers explain generic structure and give the example of generic structure of recount text. After finishing the explanation, the lecturer gives some exercise to the students. Then, the students are asked to analyze the generic structure of recount text. Furthermore, the students are asked to make recount text. After that the students make a list to generate the ideas and organized from the topic about recount text.

Moreover, the lecturer also gives worksheet to the students, it consists of three tasks, task 1, the students must arrange the picture about how to determine the characteristics of the picture and then make recount text about it. Task 2, the students must mention the generic structures and language features. Task 3, one of member must present their job in 
front of the class. In the post activity, the lecturer concludes the lesson by asking students to summarize the material. In addition, the lecturer asks about student's difficulty by giving some questions to the students. Next, the teaching learning process is evaluated to determine whether the teaching learning process run well or not. It has been stimulated to prove the existence of the learning objectives and good response are achieved from the students. There is a good interaction between lecturer and students. The lecturer gives the task and feedback and they are given to the students in the end of the meeting. The following is the result of observation checklist on the teaching learning process of recount text.

The lecturer asks the students about the attention of students to join the lesson and about their memorable experience. The students answer their unforgettable experience. Then, the lecturer starts explaining to the students about definition, generic structure and language feature about writing recount text and gives example by providing the text. Then, the lecturer explains on how to determine the characteristics of pictures that distributed by lecturer and give examples about how to make recount text based on the pictures series that given by the lecturer. The lecturers explain generic structure and give the example of generic structure of recount text. After finishing the explanation, the exercise is given to the students. Then, the students are asked to analyze the generic structure of recount text. Then, the activity is production of the text. The students are asked to make recount text. The students make a listing to generate the ideas and organized the idea from the topic about recount text. Moreover, the lecturer also gives worksheet to the students. It consists of three tasks, task 1, the students must arrange the picture about how to determine the characteristics of the picture and then make recount text about it. Task 2 , the students must mention the generic structures and language features. Task 3, one of member must present their job in front of class without paper and just take pictures series.

In the post activity, the lecturer concludes the lesson by asking to the students to summarize the material. The students answer the lecturer's questions. The lecturer asks about student's difficulty by giving some questions to the students. After meeting, the teaching learning process is evaluated to determine that the teaching learning process run well. It has been stimulated to prove the existence of the learning objectives and good response are achieved from the students. There is a good interaction not only between lecturer and students, but also among students. The lecturer gives the task to make the students understand the material well. Feedbacks are also given to the students in the end of the meeting. The following is the result of observation checklist on the teaching and learning process of recount text.

Table 1. Observation Checklist

\begin{tabular}{|c|c|c|c|}
\hline No & Questions & Yes & No \\
\hline 1 & Greeting to begin in learning process & $\checkmark$ & \\
\hline 2 & Praying together & $\checkmark$ & \\
\hline 3 & Warming up & $\checkmark$ & \\
\hline 4 & The lecturer states the objectives of the learning process & $\checkmark$ & \\
\hline 5 & The lecture explains the topic ( recount text) & $\checkmark$ & \\
\hline 6 & $\begin{array}{l}\text { The students are given opportunity to read the text and } \\
\text { explore their experience }\end{array}$ & $\checkmark$ & \\
\hline 7 & The students feel easy to write using picture series & $\checkmark$ & \\
\hline
\end{tabular}


8 The students share their experience and active in the class

9 The lecture evaluate the learning process

10 The lecture summarize and gives opportunity to the students to ask question

The data interview can be achieved from the interview with lecturer and students that aim to know the difficulty from the students and the lecturer related to the use of picture series in teaching recount text. The interview has been conducted in the class.

The result of the interview can be seen that many of the students have figured out their problems to expressing the ideas and arrange good generic structure in writing recount text. It can be proved from the discussion of the lecturer and the students. The student of AR mentions that using picture series can help to start writing. Another respond of interview from DM has mentioned that using picture series are useful to improve the students writing on recount text since most of the students write from their first language and then translate it into English. By using picture series, the students can have the ideas on how to start writing recount text well. The students can arrange the picture series to help them in composing the writing. By using picture series, the students can improve their writing . The criteria of the writing are based on the content, organization, vocabulary, language use and mechanics. Then, the result in interview with students and lecturer can be described based on the interview checklist. There are some questions given to the students to have the other result of the interview. Interview checklist relates to the materials in the teaching learning process which is provided as follow:

Table 2. Interview questions for students

\begin{tabular}{clc}
\hline No & \multicolumn{1}{c}{ Questions } & Yes \\
\hline 1 & Is using picture series useful? & $\sqrt{ }$ \\
2 & Does picture series help you to start writing? & $\sqrt{ }$ \\
3 & $\begin{array}{l}\text { Is picture series interesting and helping to improve of } \\
\text { writing? }\end{array}$ & $\sqrt{ }$ \\
4 & Does the lecturer explain the materials well & $\sqrt{ }$ \\
\hline
\end{tabular}

Table 3. Interview questions for lecturer

\begin{tabular}{clc}
\hline No & \multicolumn{1}{c}{ Questions } & Yes \\
\hline 1 & Do you think that the students are interested in the class? & $\sqrt{ }$ \\
2 & Can picture series help the students to start writing? & $\sqrt{ }$ \\
3 & Is picture series interesting and helping to improve writing? & $\sqrt{ }$ \\
4 & $\begin{array}{l}\text { Do the students understand well in writing using picture } \\
\text { series? }\end{array}$ & $\sqrt{ }$ \\
\hline
\end{tabular}


The documentation was obtained from the lesson plan and student writing from the fourth semester students of midwifery program of STIKES BHM Madiun. Based on the data, the application of teaching using picture series in teaching recount text was divided into two steps. There are preparation and application of using picture series in writing recount text. The lecturer makes the lesson plan before starting the teaching learning process in the classroom. The lesson plan is completely written. The lesson plan is used to guide the teaching learning process in writing class and help the lecturers By using the lesson plan, teaching objectives can be achieved and minimize the errors in the teaching and learning process. After that, the lecturer begins teaching writing on recount text.

The result can be seen that the activity in this step can be done successfully by students. In this preparation, teacher prepares lesson plan and materials. The lecturer must master teaching materials and comprehend the methods which also need appropriate evaluation, media and teaching environment. Teaching using picture series in writing recount text is useful to improve the students writing score. It can be seen from the result of the students' score in the following diagram.

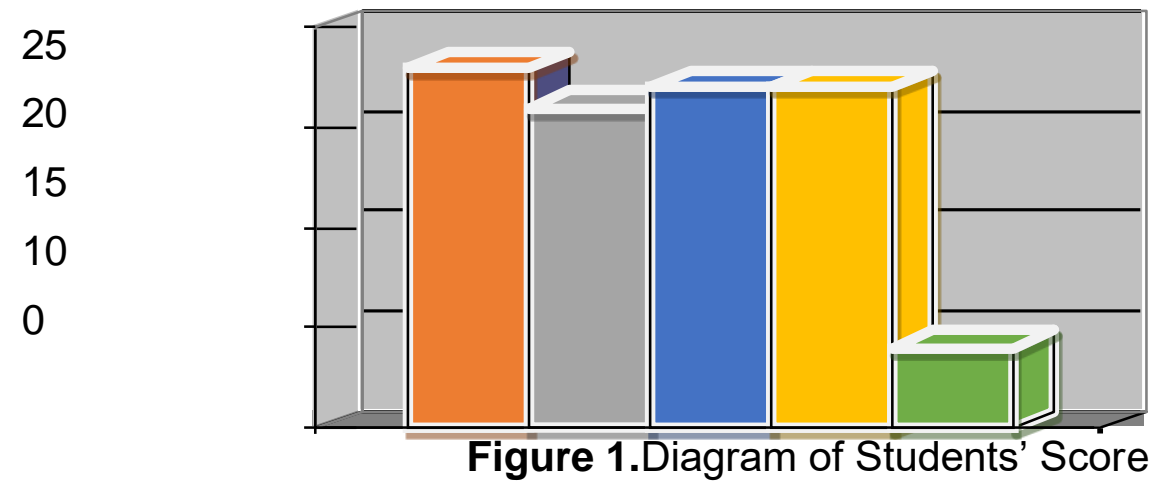

Based on the explanation above, it can be seen that the use of picture series in teaching writing can help the students compose the recount text well. The diagram shows that the criteria of writing can be achieved well by the students. The average of the content shows 23 . The average of organization shows 20 . The average of the students' vocabulary is 21 . The average of language shows 21 . The last, the students show that the average of using mechanics is 8 . The average of the students' scores is 73 . It can be concluded that the teaching learning using picture series was done successfully. And the use of picture series in teaching writing recount text make the students are interested and focus on lecturers' explanation about the material. Thus, the learning process is supported that the students are better to write from the results of their experiences to compose recount text.

Based on the findings above, it can be concluded that the use of picture series in teaching recount text for the fourth semester students of midwifery program of STIKES BHM Madiun is successful. There are many reasons and implications the use of picture series in teaching recount text.

Using picture series can help the students to express their ideas creatively and create their ideas while arranging the pictures. Those pictures are interesting because those are prepared well than that using the text. It is supported by Mayasari (2014) stating that using picture series can help the students to generate and organize their ideas. Putra (2014) reported that the students can get more ideas by paying attention to the picture series when writing recount text. It represents a good stimulus to take initiative, discuss, and write among 
the picture series. Thus, it is an easy way of bringing the outside world into the classroom to enrich the students' text about recount text.

Using pictures can help the students to have better writing skill. The students can enjoy the process so that they can manage well how to write. The students achieve better scores on the content, vocabulary, language use, and organization. It is supported by Saputri (2014) that the use of picture series can improve the students' skills in writing. This can be seen from the significant improvements of the students' writing in the aspects of content, organization, language use, vocabulary, and mechanics.

Other sources such as Mansourzadeh (2014) reported that pictures help the students to know the difficult words easily by looking at the pictures. The use of pictures can enlarge the students' vocabulary learning. It attracts the students' curiosity in learning new vocabulary. Furthermore, concerning with the other benefits of writing recount text through picture series, it is effectively used in helping students' improve their performance in writing recount text. Gutiérrez et al., (2015) mentioned that pictures help students enlarge their vocabulary usage by utilizing words. It is also providing visual feedback of the objects and actions described in writing especially in recount text. Styati (2016) identified that using pictures can help the students in writing performance. In fact, this study compares the use of using picture series and YouTube videos. Using picture series is effectively to help the students in writing. This study also reports that the students writing performance based on the criteria of content, organization, vocabulary, grammar and mechanics.

The use of picture enhances the students' motivation and interest. They are more motivated to join the writing class because of better use of media. So that they are very happy in writing recount text because the use of pictures can attract the students to write well in recount text writing. Using pictures can reinforce the students' experience in the past because recount text retells the experience that the students have experienced. Hazanah (2011) said that the use of picture sequence can have better arrangement on the organization of writing related to the ideas. Thus, this indicates that there are several benefits from the use of picture series in teaching writing. The benefits raise the development of students' writing performance, the increasing of students' motivation in the class, enhancement of learning environment and the increasing of students' writing interest. It is worth automatically to provide practice for students with various ability levels in teaching writing recount text.

Using picture series can help the students to express their ideas more creatively and help the students to have better writing skill. Morevoeve, it can enhance the students' motivation and interest. Finally, the use of picture series is effectively used in helping students' improve their performance in writing recount text.

\section{Conclusion}

The use of picture series in teaching recount text for the fourth semester students of midwifery program of STIKES BHM Madiun has been done successfully. It makes the students are interested and focusing on explanation about the material very well in the classroom. Thus, it supports the students to develop their skills in writing starting from their experiences. The use picture series can help the students to express their ideas and can enhance the students' motivation and interest at writing. Moreover, it helps students to improve their performance in writing recount text. Therefore, the use of picture series in teaching recount text can be achieved successfully. 
Based on the conclusions above, the students' writing recount text through picture series is not a new thing in the field of teaching to develop the students' competence of writing. In teaching writing skill, the teacher should realize the difficulty of the students. The lecturer needs the easier way on how to help the students to start writing. Thus, the lecturer should be innovative to guide the students in writing and be able to create a good and comfortable environment in the class.

The future researcher may conduct the use of picture series in other skills of English such as speaking skill. It can be used as the easy media to express the students' creativity in their speaking. Furthermore, the researcher can expand this study by using another design such as the experimental research design to find better media in teaching English writing skill.

\section{References}

Apsari, Y, A. (2017). The Use of Picture Series in Teaching Writing Recount Text.ELTIN Journal, 5(2).

Arikunto, S. (2010).ProsedurPenelitian. Jakarta: RinekaCipta.

Azhari,R. (2004). Teaching Descriptive Writing by Using Picture Among Third Grade Students of SLTP Negeri 18 Malang. Unpublished Thesis English Language Education, Graduate Program of State University of Malang

Berk, R. A. (2009). Multimedia teaching with video clips: TV, movies, YouTube, and mtvU in the college classroom. International Journal of Technology in Teaching and Learning, 5(1), 1-2.

Braine, George ,\& May, C. (1992). Writing from Source .London : Myfield Company.

Dinamikallmu, 16(2).

Gutiérrez, K.G.C., Puello, N.N \&amp; Galvis, L. A. P. (2015).Using Pictures Series Technique to Enhance Narrative Writing among Ninth Grade Students at InstituciónEducativaSimónAraujo. English Language Teaching, 8(5).

Hazanah, Y. A. (2011). Using Pictures Sequences to Improve Students' Ability in Writing Narative Texts. In Best Practices in the Teaching of English(pp. 261-273). Malang: State University of Malang Press.

Mansourzadeh, N. (2014). A Comparative Study of Teaching Vocabulary through Pictures and Audio-visual Aids to Young Iranian EFL Learners. Journal of Elementary Education, 24(1), 47-59.

Mardiana,Albert,\&Dewi. (2014). Teaching Recount Text Writing Using Picture Series'.

Mayasari, E.A. (2014). Using Picture Series to Improve the Writing Ability of the Eighth Grade Students at SMP Negeri 2 Wonosari in the Academic Year of 2013/2014. Yogyakarta State University: Unpublished Thesis

Rahman, M. (2013).Using Authentic Materials in the Writing Classes: A Tertiary Level Scenario.BRAC University.

Saputri, I. W. (2014). Improving the Writing Skills of Recount Texts by Using Picture Series for the Eighth Grade Students of SmpMuhammadiyah 2 Kalasan in the Academic Year of 2013/2014. Yogyakarta State University. 
Styati, E.W. (2016). Effect of YouTube Videos and Pictures on EFLStudents' Writing Performance.

Styati, E.W., \&Latief, M. A. (2018). Investigating Dominant and Passive Students on Pair Work towards the Students' Writing Performance. 3L: Language, Linguistics, Literature, 24(3). https://doi.org/10.17576/3L-2018-2403-11

Sukardi.(2006). Penelitian Kualitatif Naturalistik Dalam Pendidikan. Yogyakarta: Usaha Keluarga.

Syafi'i.L. (2016). The Use of Picture Series to Improve Eight Grade 'Writing Recount Text' 